\title{
Management of Tomato Bacterial Spot in the Field by Foliar Applications of Bacteriophages and SAR Inducers
}

A. Obradovic and J. B. Jones, Department of Plant Pathology, University of Florida, Gainesville 32611; M. T. Momol, Plant Pathology Department, North Florida Research and Education Center, University of Florida, Quincy 32351; B. Balogh, Department of Plant Pathology, University of Florida, Gainesville; and S. M. Olson, Horticultural Sciences Department, North Florida Research and Education Center, University of Florida, Quincy

\begin{abstract}
Obradovic, A., Jones, J. B., Momol, M. T., Balogh, B., and Olson, S. M. 2004. Management of tomato bacterial spot in the field by foliar applications of bacteriophages and SAR inducers. Plant Dis. 88:736-740.

Various combinations of the harpin protein, acibenzolar-S-methyl, and bacteriophages were compared for controlling tomato bacterial spot in field experiments. Harpin protein and acibenzolar-S-methyl were applied every 14 days beginning twice before transplanting and then an additional four applications throughout the season. Formulated bacteriophages were applied prior to inoculation followed by twice a week at dusk. A standard bactericide treatment, consisting of copper hydroxide plus mancozeb, was applied once prior to inoculation and then every 7 days, while untreated plants served as an untreated control. Experiments were conducted in north and central Florida fields during fall 2001, spring 2002, and fall 2002. In three consecutive seasons, acibenzolar-S-methyl applied in combination with bacteriophage or bacteriophage and harpin significantly reduced bacterial spot compared with the other treatments. However, it did not significantly affect the total yield compared with the standard or untreated control. Application of host-specific bacteriophages was effective against the bacterial spot pathogen in all three experiments, providing better disease control than copper-mancozeb or untreated control. When results of the disease severity assessments or harvested yield from the bacteriophage-treated plots were grouped and compared with the results of the corresponding nonbacteriophage group, the former provided significantly better disease control and yield of total marketable fruit.
\end{abstract}

Tomato bacterial spot, caused by Xanthomonas campestris pv. vesicatoria (Doidge) Dye, remains a constant threat to tomato (Lycopersicon esculentum Mill.) commercial production $(6,19,35)$. Control strategies are based on a combination of practices such as use of pathogen-free seed and transplants, elimination of volunteer tomato plants, resistant cultivars, and frequent application of a copper and mancozeb mixture $(21,24,38)$. Chemical control has been used extensively for controlling bacterial spot. In the 1950s, streptomycin was used, but resistant bacterial strains developed and rendered antibiotics ineffective (39). However, these strategies are of limited use, especially in the tropics and subtropics where weather conditions favor infection (26). Four tomato races (T1 to T4) of $X$. campestris pv. vesicatoria have been described $(23,31)$.

Corresponding author: J. B. Jones

E-mail: jbjones@ufl.edu

This research was supported by grants from the USDA Southern Region IPM and USDA T-STAR programs.

Accepted for publication 10 March 2004.

Publication no. D-2004-0511-01R

(C) 2004 The American Phytopathological Society
However, only two races (T1 and T3) commonly occur in Florida $(22,23)$, whereas $\mathrm{T} 4$ has been found recently at a very low incidence (31). In Florida, T3 has become the most prevalent race $(12,17)$. Although resistance genes have been identified and introgressed into tomato and pepper genotypes with good horticultural qualities, shifts in race populations of $X$. campestris pv. vesicatoria compromise breeders' efforts to provide stable resistance in commercial tomato cultivars $(23,25)$.

Chemical control of bacterial spot relies on multiple applications of copper- or streptomycin-based bactericides (26). However, the occurrence of pathogenic strains tolerant to these compounds reduces their effectiveness significantly $(29,36,39)$. As a result of the build-up in copper-tolerant strains, a mixture of copper and ethylene-bis-dithiocarbamates was used to control these strains $(9,24,29)$. Although copper-mancozeb combinations reduced bacterial populations on tomato leaves (24) and resulted in improved disease control $(9,24)$, the combination was ineffective when weather conditions were optimal for disease development, and positive yield responses rarely were observed in situations where copper-tolerant strains were present (18). Therefore, alternative disease control strategies are needed that result in improved disease control and yield responses. Alternative strategies that have been tested and which were associated with a reduction in disease severity of bacterial spot and bacterial speck of tomato include activation of natural plant defense mechanisms by systemic acquired resistance (SAR) inducers $(28,35,37)$ and plant growth-promoting rhizobacteria (PGPR) (14,33), and application of antagonistic bacteria $(41,42)$ and bacteriophages $(3,10,20)$.

Although biological control agents have been used successfully for control of crown gall, caused by Agrobacterium tumefaciens (7), and fire blight of pear, caused by Erwinia amylovora (27), their application to xanthomonads has been tested only in a limited manner. Bacillus spp. provided complete control of black rot on crucifer $(1,2)$. In greenhouse studies, $E$. herbicola and Bacillus subtilis suppressed $X$. campestris pv. vignicola on cowpea and $X$. campestris pv. vignearadiatae on mung bean $(15,16)$. The only published information on bacterial antagonism by nonpathogenic strains toward the bacterial spot of tomato pathogen is that of Colin et al. (8), who determined in in vitro experiments that Pseudomonas spp. were antagonistic toward X. campestris pv. vesicatoria. Besides nonpathogenic bacteria, plantpathogenic bacterial strains have been shown to be antagonistic to strains of closely related bacteria (40). T3 strains were shown to be antagonistic to $\mathrm{T} 1$ strains by producing bacteriocin-like compounds. The T3 strains were shown to contain at least three different bacteriocins that were inhibitory to T1 strains. Hert (12) demonstrated that two of the bacteriocins were essential for the competitive advantage of $\mathrm{T} 3$ strains over $\mathrm{T} 1$ strains. The antagonistic nature of the T3 strains $(17,40)$ helps to explain previously published results in which T3 strains were shown to outcompete T1 strains in fields where both strains were present (17).

In order to integrate some of these methods to optimize their benefits in control of tomato bacterial spot, we studied the combined effects of SARs, PGPRs, bacteriophages, and antagonistic bacteria under greenhouse conditions (33). We identified several combinations of SARs and bacteriophages that effectively reduced bacterial spot on tomato. Based on results 
from the greenhouse experiments, our objectives in this study were to demonstrate the importance of bacteriophages and SARs alone and in combination for control of bacterial spot and increased yield under field conditions.

\section{MATERIALS AND METHODS}

Inoculum production and inoculation. A copper-sensitive strain of $X$. campestris pv. vesicatoria tomato race 3 (91-118) was stored in $30 \%$ glycerol at $-80^{\circ} \mathrm{C}$. Before use, it was grown in nutrient broth medium (0.8\% nutrient broth, BBL; Becton Dickinson and Co., Cockeysville, MD) on a rotary shaker at $28^{\circ} \mathrm{C}$. After $24 \mathrm{~h}$, bacteria were harvested by centrifugation and resuspended in sterile tap water. The concentration was adjusted by measuring optical density at $600 \mathrm{~nm}\left(\mathrm{OD}_{600}=0.3\right.$, equivalent to $10^{8} \mathrm{CFU} / \mathrm{ml}$ ). Inoculum of the $X$. campestris pv. vesicatoria strain was prepared by diluting the suspension $1: 100(\mathrm{vol} / \mathrm{vol})$ in sterile water and then surfactant Silwet L-77 (Loveland Industries Inc., Greeley, $\mathrm{CO}$ ) was added to a final concentration of $0.025 \%$ ( $\mathrm{vol} / \mathrm{vol})$. Prior to setting into the field, tomato transplants were inoculated by spraying the $X$. campestris pv. vesicatoria inoculum until run-off using a hand-held mechanical mister.

Field studies. Experiment 1. The experiment was conducted at the North Florida Research and Education Center (NFREC) in Quincy, FL, during fall 2001. Tomato cv. BHN555 transplants were grown in 128-cell float containers in a greenhouse for 6 weeks. Prior to transplanting, the bacterial suspension was sprayed on the transplants in the early morning on 3 August. Following inoculation, plants were transplanted into the field in single rows covered with black plastic mulch. The experiment was designed as a randomized complete block design, with
10 treatments (Table 1) and four replications. Each plot consisted of a single row of 12 plants. Plants were spaced $51 \mathrm{~cm}$ apart within plots and $6.1 \mathrm{~m}$ between plots. Based on results from greenhouse experiments (33), the following compounds were selected for control of tomato bacterial spot in the field: copper hydroxide (Kocide 2000; Griffin Corp., Valdosta, GA) + mancozeb (Manzate 75DF; Griffin Corp.) (Cu$\mathrm{Mz}$ ), harpin protein (Messenger, Eden Bioscience), acibenzolar-S-methyl (ASM, or benzothiadiazol [BTH], Actigard 50 WG; Syngenta Inc.), and bacteriophages (Agriphage; OmniLytics, Inc., Salt Lake Cith, UT). In this experiment, $\mathrm{Cu}-\mathrm{Mz}$ was used as the standard treatment and untreated plants (UTC) as control. Harpin and ASM, which are SAR inducers, were applied every 14 days either alone or in combination with other treatments. ASM was limited to six applications per season. When included in the same treatment, harpin and ASM were sprayed alternately, with 1 week between applications and 2 weeks between spraying of the same compound. The bacteriophage mixture (phage) contained six different phages specific to $X$. campestris pv. vesicatoria race $\mathrm{T} 3$ strain 91-118 and was formulated with casecrete (5 g/liter, Casecrete NH-400; American Casein Company, Burlington, NJ), pregelatinized corn flour (2.5 g/liter, PCF 400; Lauhoff Grain Co., Danville, IL), and sucrose $(5 \mathrm{~g} /$ liter $)$ in order to prolong phage longevity $(3,4)$. The bacteriophage was used at a $1 \%$ concentration of the commercial phage preparation containing approximately $10^{10}$ plaque forming units (PFU) per milliliter. Phage was applied twice per week at dusk. Nonchlorinated water was used to prepare harpin and phage for spraying. The experiment was maintained with conventional fertilization, drip irrigation, and disease, weed, and insect control (30).
Foliar disease severity was assessed by estimating the percent leaf area affected (necrotic tissue) by bacterial spot using the Horsfall-Barratt (HB) rating scale (13) starting 1 month after inoculation and every second week thereafter. Fruit were harvested twice; graded into medium, large, and extra-large size fruit (11); and the weight for each class and the total marketable yield were calculated. The data were analyzed statistically using SAS software (SAS Institute, Cary, NC) and differences between means were determined by Duncan's multiple range test $(P \leq 0.05)$.

Experiment 2. The experiment was conducted at the Plant Science Research and Education Unit, Citra, FL, during spring 2002. Five-week-old transplants of tomato cv. BHN444 were planted into the field on 25 April. In order to reduce the likelihood of phage spreading to nonphage plots, the trial was designed as a split plot with the main plot being phage versus no phage application, with a spacing of $45 \mathrm{~m}$ between main plots in four replications. Each subplot consisted of 14 plants spaced 45 $\mathrm{cm}$ apart. The subplot treatments (Table 1) were applied following the same procedures described for experiment 1 and consisted of an untreated control, $\mathrm{Cu}-\mathrm{Mz}$, two SAR inducers (harpin and ASM), bacteriophages, and a combination of SAR inducers and phage. Phages were formulated with skim milk $(7.5 \mathrm{~g} /$ liter, instant nonfat dry milk, fortified with vitamins A and D, distributed by Publix Super Markets, Inc.) and sucrose $(5 \mathrm{~g} /$ liter) based on the results of Balogh et al. (4), which simplified the procedure of formulating phage mixture for spraying. Foliar disease severity and fruit yield were assessed, and data were collected and analyzed as indicated for experiment 1 .

Experiment 3. The experiment was conducted in Citra, FL with tomato cv. BHN555 in fall 2002. The experimental

Table 1. Treatments tested for control of tomato bacterial spot in the field during fall 2001 and spring and fall 2002

\begin{tabular}{|c|c|c|c|c|c|c|c|}
\hline \multirow[b]{3}{*}{ Treatments $^{\mathrm{x}}$} & \multirow[b]{3}{*}{ Concentration $^{y}$} & \multirow[b]{3}{*}{ Timing } & \multicolumn{5}{|c|}{ Field experiments ${ }^{w}$} \\
\hline & & & \multicolumn{2}{|c|}{1} & \multicolumn{2}{|c|}{2} & \multirow{2}{*}{$\begin{array}{c}3 \\
\text { AUDPC }\end{array}$} \\
\hline & & & AUDPC & Yield (t/ha) & AUDPC & Yield (t/ha) & \\
\hline UTC & None & None & $164.5 \mathrm{ab}$ & $60.8 \mathrm{a}$ & $161.0 \mathrm{a}$ & $29.8 \mathrm{abc}$ & $91.38 \mathrm{a}$ \\
\hline $\mathrm{Cu}-\mathrm{Mz}$ & $0.19 \%+0.18 \%$ & 1 & $177.6 \mathrm{a}$ & $61.3 \mathrm{a}$ & $124.3 \mathrm{bc}$ & $34.6 \mathrm{abc}$ & $66.63 \mathrm{~b}$ \\
\hline Harpin & $0.0018 \%$ & 2 & $159.3 \mathrm{bc}$ & $66.2 \mathrm{a}$ & $152.3 \mathrm{a}$ & $27.3 \mathrm{c}$ & $85.38 \mathrm{a}$ \\
\hline Harpin, ASM & $\ldots$ & $\ldots$ & $147.0 \mathrm{bcd}$ & $61.4 \mathrm{a}$ & $133.0 \mathrm{~b}$ & $30.4 \mathrm{abc}$ & nt \\
\hline Harpin, ASM, Cu-Mz & $\ldots$ & $\ldots$ & $143.5 \mathrm{~cd}$ & $61.1 \mathrm{a}$ & $\mathrm{nt}$ & nt & nt \\
\hline ASM & $0.003 \%$ & 3 & $133.9 \mathrm{de}$ & $65.5 \mathrm{a}$ & $131.3 \mathrm{~b}$ & $27.0 \mathrm{c}$ & $57.88 \mathrm{~b}$ \\
\hline Phage & $1 \%$ & 4 & $137.4 \mathrm{~d}$ & $69.4 \mathrm{a}$ & $108.5 \mathrm{~cd}$ & $34.3 \mathrm{abc}$ & $53.50 \mathrm{bc}$ \\
\hline Phage, $\mathrm{Cu}-\mathrm{Mz}$ & $\ldots$ & $\ldots$ & nt & nt & $98.0 \mathrm{~d}$ & $36.1 \mathrm{ab}$ & $38.63 \mathrm{~cd}$ \\
\hline Phage, harpin & $\ldots$ & $\ldots$ & $152.3 \mathrm{bcd}$ & $71.8 \mathrm{a}$ & $105.0 \mathrm{~d}$ & $37.9 \mathrm{a}$ & $54.63 \mathrm{bc}$ \\
\hline Phage, harpin, ASM & $\ldots$ & $\ldots$ & $112.9 \mathrm{f}$ & $66.1 \mathrm{a}$ & $99.8 \mathrm{~d}$ & $31.9 \mathrm{abc}$ & nt \\
\hline Phage, ASM & $\ldots$ & $\ldots$ & 117.3 ef & $67.9 \mathrm{a}$ & $101.5 \mathrm{~d}$ & $30.1 \mathrm{abc}$ & $34.75 \mathrm{~d}$ \\
\hline
\end{tabular}

${ }^{\mathrm{w}}$ AUDPC $=$ area under the disease progress curve. Means followed by the same letter within a column are not significantly different according to Duncan's multiple range test, $P=0.05$ level; $\mathrm{nt}=$ not tested.

${ }^{x}$ UTC $=$ untreated control, Cu-Mz = copper-mancozeb (Kocide $2000+$ Manzate 75DF, Griffin Corporation, Valdosta, GA), Harpin = harpin protein (Messenger, Eden Bioscience, ASM = acibenzolar-S-methyl (Actigard 50 WG, Syngenta Inc., and Phage = agriphage (OmniLytics, Inc., Salt Lake City, UT).

y ... Indicates applied respectively in concentration and timing indicated for particular treatment.

${ }^{\mathrm{z}}$ Application timing: 1 = once prior inoculation, after that weekly; 2 = two applications before inoculation, then at 2 -week intervals; $3=$ two applications before inoculation, then at 2-week intervals, limited to six applications; and $4=$ once prior inoculation, then twice a week at dusk. 
design, application of treatments, crop maintenance, and data processing were as described in experiment 2 . The plants were transplanted to the field on 12 August at similar spacing between plants within plots and between plots as in experiment 2 . We focused on the effects of SAR inducers and their combinations with phage mixtures. Therefore, only four treatments (UTC, Cu$\mathrm{Mz}$, harpin, and ASM) were applied alone and in combination with phage (Table 1).

\section{RESULTS}

In Quincy during fall 2001 (experiment 1), all treatments significantly reduced disease severity compared with the $\mathrm{Cu}-\mathrm{Mz}$ treatment (Table 1). According to the area under the disease progress curve (AUDPC) results, the combination of phage and SAR inducers and phage plus ASM provided the best disease control (Table 1). However, this did not correlate with the yield data. When the total marketable fruit yield was analyzed, no statistically significant differences between treatments were observed (Table 1). Although standard statistical analysis showed no significant difference in yield between treatments, there appeared to be a trend of higher yield harvested from plots treated with phage, either

\section{Experiment 1}

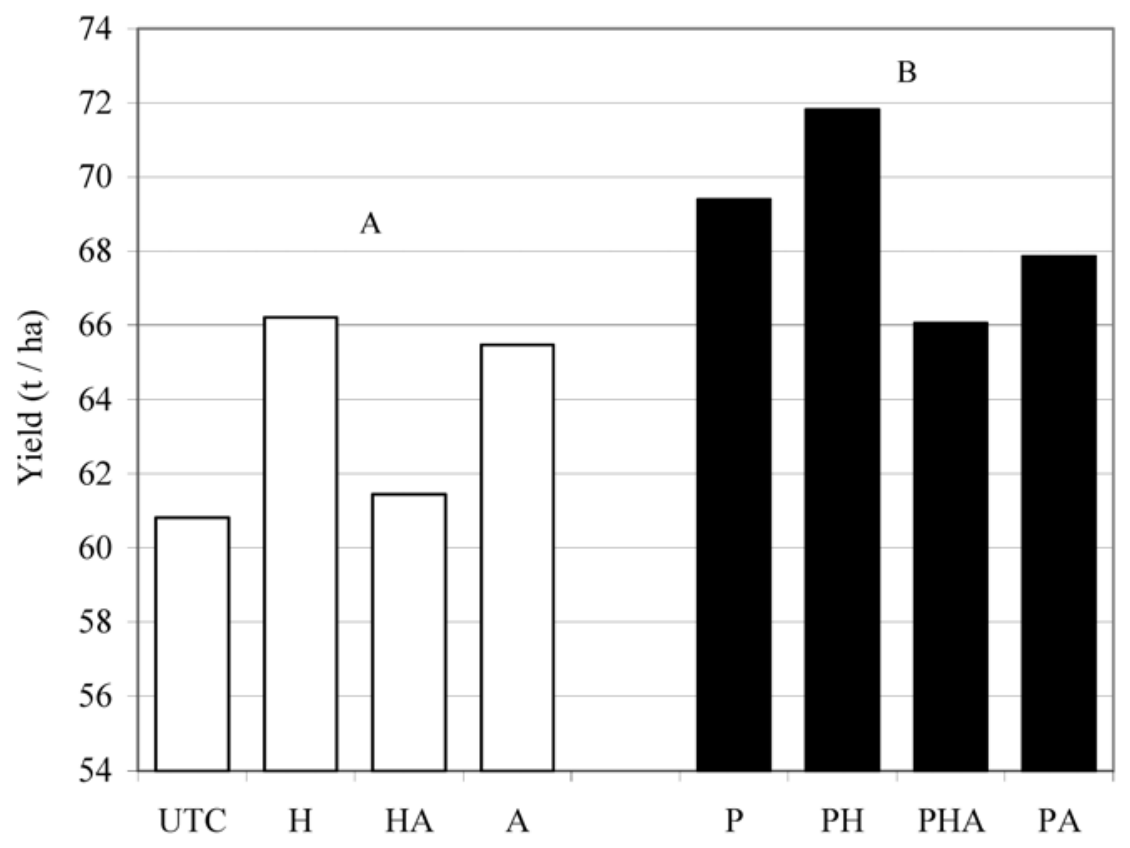

Experiment 2

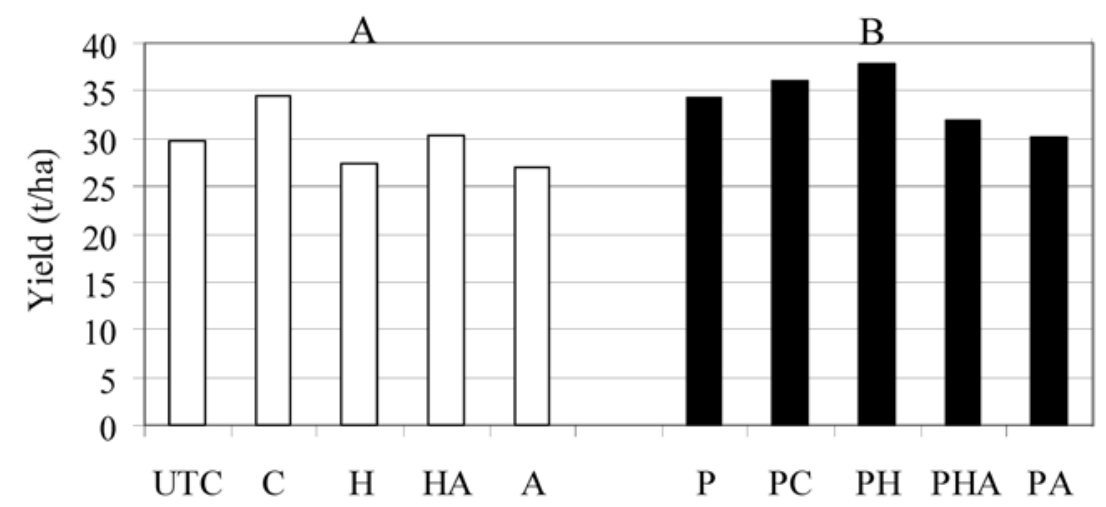

Fig. 1. Contrast analysis of total marketable fruit yield (t/ha) of tomato cv. BHN555 (experiment 1) and BHN444 (experiment 2) from nonphage-treated (white bars) versus phage-treated (black bars) plots. Abbreviations on horizontal axis correspond to the treatments listed in Table 1: UTC $=$ untreated control, $\mathrm{C}=$ copper-mancozeb, $\mathrm{H}$ = harpin, $\mathrm{A}=$ acibenzolar- $S$-methyl, $\mathrm{P}=$ phage. For contrast analysis, phage-treated plots were compared with nonphage-treated plots and showed that yields were significantly different $(P=0.05)$ in both years.

alone or in combination (phage, phageharpin, phage-harpin-ASM, and phageASM; Table 1) than in plots receiving no phage applications. Therefore, we analyzed the data by contrast analysis using the SAS CONTRAST statement, grouping the phage treatments (phage, phage-harpin, phage-harpin-ASM, and phage-ASM) and comparing them with either $\mathrm{Cu}-\mathrm{Mz}$ treatments $(\mathrm{Cu}-\mathrm{Mz}$ and harpin-ASM-Cu-Mz; Table 1) or corresponding nonphage treatments (UTC, harpin, harpin-ASM, and ASM). These results indicated significant differences between the groups used for comparison in favor of the group with phage application included (Fig. 1, experiment 1).

In experiment 2 (Citra, spring 2002), the disease severity analysis showed a major difference between phage and nonphage treatments where the phage treatments provided significantly better control of tomato bacterial spot (Table 1). No significant variation between phage treatments was observed; whereas, in the other group, $\mathrm{Cu}-\mathrm{Mz}$ and ASM reduced the disease severity significantly more than harpin or the UTC. Yield data analysis showed an effect of the treatments similar to that in the previous experiment. The highest yield was harvested from plots treated with phageharpin combination (Table 1). It was significantly higher than yield from harpin- or ASM-treated plots, but not compared with the rest of the treatments or UTC. However, the phage treatments had yield significantly higher than the nonphage treatments when grouped and compared in contrast analysis (Fig. 1, experiment 2). No significant difference in yield was found by contrast analysis of non-ASM treatments versus corresponding ASM treatments in both experiments (Fig. 2).

The combination of phage and ASM was the most effective treatment during fall 2002. It prevented development of bacterial spot symptoms significantly better than the other treatments (Table 1). However, the highest disease severity was recorded on UTC and harpin-treated plots. Phage application significantly lowered the disease severity. This treatment and its combination with $\mathrm{Cu}-\mathrm{Mz}$, harpin, or ASM provided better disease control compared with corresponding nonphage treatments (Table 1). In this experiment, yield data were not collected due to spread of virus infection on most of the plants.

\section{DISCUSSION}

In this study, we demonstrated that alternative methods for management of tomato bacterial spot can effectively control bacterial spot of tomato and also result in increased yield. Based on results from greenhouse experiments in which we compared bacterial antagonists, PGPRs, SAR inducers, and bacteriophages (33), we focused on application of SAR inducers and host-specific bacteriophages. Applica- 
tion of bacteriophages constantly provided a significant reduction in bacterial spot severity compared with the untreated control. The success of the bacteriophages in this study was enhanced, in all likelihood, by mixing with skim milk and sucrose as described by Balogh et al. (4), in which the formulated phage contributed to greater stability of bacteriophages on leaf surfaces. Although copper-sensitive strains were used in this study which favor more effective control of bacterial spot with copper bactericides, phages were either more effective or equally effective compared with the $\mathrm{Cu}-\mathrm{Mz}$ treatment. Being naturally occurring, environmentally friendly, and highly specific to the pathogen, phages are very promising as an alternative to streptomycin or copper-based bactericides, especially in those areas where copper- or streptomycinresistant strains of $X$. campestris pv. vesicatoria predominate $(29,39)$.

The SAR compound, ASM, was shown to control bacterial spot when applied alone, which agreed with previous results (28). However, ASM was not as effective for controlling bacterial spot in the field as was observed in greenhouse experiments (33). The combination of phage and the SAR compound, ASM, proved quite effective in control of bacterial spot of tomato and was superior to disease control achieved by phage alone in two of three experiments. Although defense mechanisms induced by ASM could not completely prevent occurrence of the disease, plants treated with ASM alone had significantly less disease induced by bacterial spot than the untreated control. The combination of ASM and phage provided an additional reduction in disease pressure and resulted in more efficient foliar disease control than ASM, phage, or $\mathrm{Cu}-\mathrm{Mz}$. Harpin, on the other hand, did not reduce bacterial spot severity when applied alone or in combination with phage.

Phage-treated plants produced significantly more marketable fruit than plants
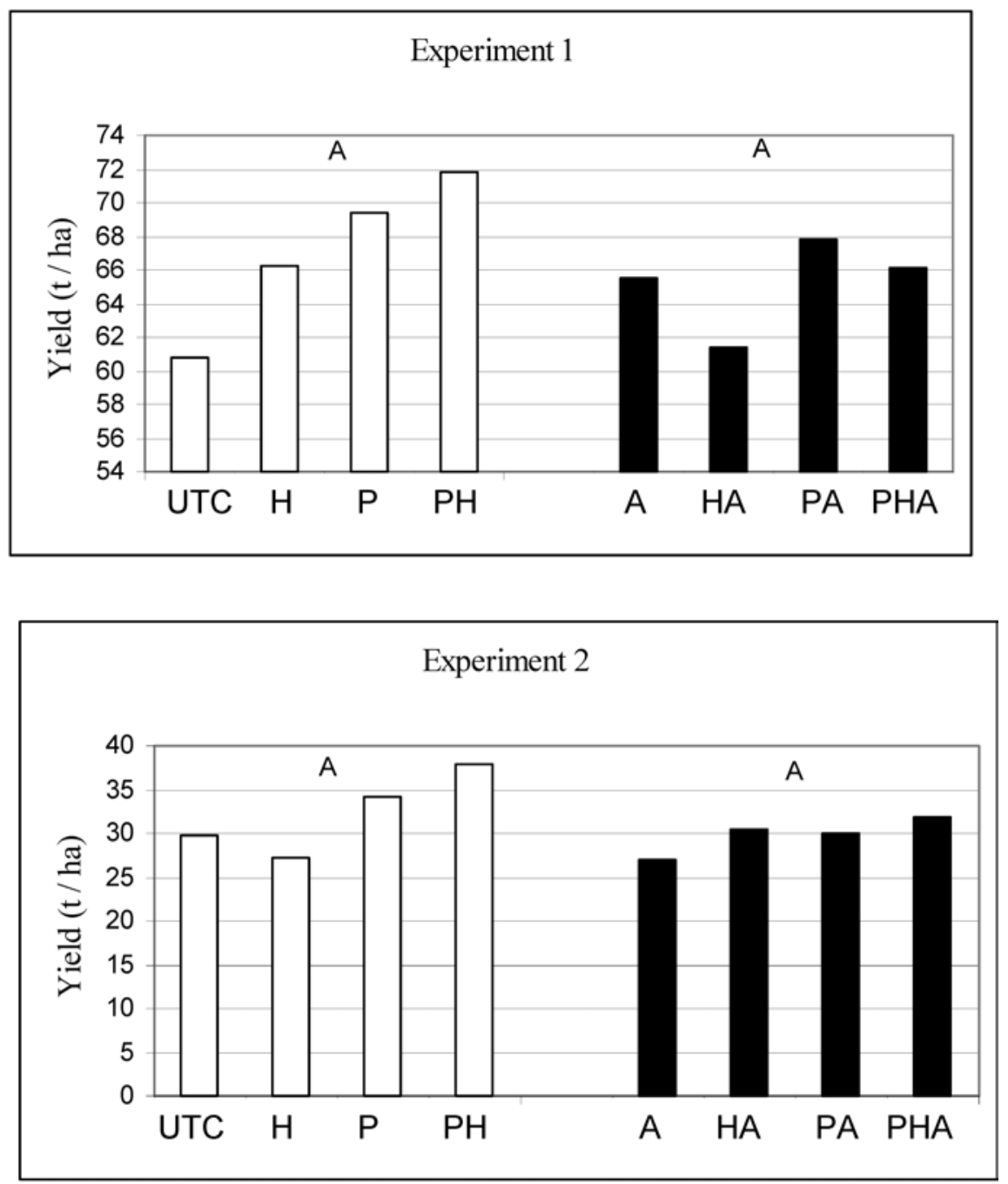

Fig. 2. Contrast analysis of total marketable fruit yield (t/ha) of tomato cv. BHN555 (experiment 1) and BHN444 (experiment 2) from non-acibenzolar-S-methyl (ASM)-treated (white bars) versus ASMtreated (black bars) plots. Abbreviations on horizontal axis correspond to the treatments listed in Table 1: UTC = untreated control, $\mathrm{C}=$ copper-mancozeb, $\mathrm{H}=$ harpin, $\mathrm{A}=\mathrm{ASM}, \mathrm{P}=$ phage. For contrast analysis, ASM-treated plots were compared with non-ASM-treated plots and showed that yields were not significantly different $(P=0.05)$ in both years. not receiving phage. Although disease control was effectively achieved using the combination of phage and ASM, yield was not as favorably affected by the combination. The quantity of marketable fruit harvested from ASM-treated plots was numerically lower but statistically insignificant from the yield harvested from nonASM plots. Based on these experiments, the combination of ASM and bacteriophage may be an effective new tool for tomato growers to manage bacterial spot. The fact that ASM can trigger a natural defense response against other tomato diseases $(5,32)$ increases the potential benefit of this compound in integrated disease management. In related bacterial wilt field studies, ASM was determined to enhance resistance to and result in significant yield increases in tomato cultivars with moderate levels of resistance to the bacterial wilt pathogen (P. Pradhanang, M. T. Momol, P. Ji, S. M. Olson, J. Mayfield, and J. B. Jones, unpublished results). Therefore, ASM offers potential for controlling multiple bacterial diseases.

Although harpin did not reduce bacterial spot severity, plants treated with the combination of harpin and phage had, numerically, the highest total marketable yield in 2001 and 2002. Further work is necessary to determine the beneficial aspects of harpin. Therefore, harpin appears to behave more as a growth-promoting compound rather than as a SAR for bacterial spot disease control.

\section{ACKNOWLEDGMENTS}

We thank P. King and J. Snell for their technical assistance.

\section{LITERATURE CITED}

1. Assis, S. M. P., Mariano, R. L. R., Michereff, S. J., and Coelho, R. S. B. 1996. Survival and redistribution of Bacillus spp., potential biological control agents of black rot on kale phylloplane. Pages 374-379 in: Advances in Biological Control of Plant Disease. T. Wenhua, R. J. Cook, and A. Rovira, eds. Agricultural University Press, Beijing, China.

2. Assis, S. M. P., Mariano, R. L. R., Michereff, S. J., and Rildo, S. B. 1996. Biological control of Xanthomonas campestris pv. campestris on kale with Bacillus spp. and endophytic bacteria. Pages 347-353 in: Advances in Biological Control of Plant Disease. T. Wenhua, R. J. Cook, and A. Rovira, eds. Agricultural University Press, Beijing, China.

3. Balogh, B. 2002. Strategies for improving the efficacy of bacteriophages for controlling bacterial spot of tomato. Master's thesis. University of Florida, Gainesville.

4. Balogh, B., Jones, J. B., Momol, M. T., Olson, S. M., Obradovic, A., King, P., and Jackson, L. E. 2003. Improved efficacy of newly formulated bacteriophages for management of bacterial spot on tomato. Plant Dis. 87:949954.

5. Benhamou, N., and Belanger, R. R. 1998 Benzothiadiazole-mediated induced resistance to Fusarium oxysporum f. sp. radicis-lycopersici in tomato. Plant Physiol. 118:1203-1212.

6. Bouzar, H., Jones, J. B., Stall, R. E., Louws, F. J., Schneider, M., Rademaker, J. L. W., de Bruijn, F. J., and Jackson, L. E. 1999. Multiphasic analysis of xanthomonads causing bac- 
terial spot disease on tomato and pepper in the Caribbean and Central America: Evidence for common lineages within and between countries. Phytopathology 89:328-335.

7. Clare, B. G. 1993. Agrobacterium: Biological plant disease control. Pages 129-146 in: Advanced Engineered Pesticides. L. Kim, ed. Marcel Dekker, New York.

8. Colin, J., Pussemier, L.,, and Diouf, A.M. 1984. Demonstration and application of the antagonism of fluorescent Pseudomonas spp. toward phytopathogenic. Meded. Fac. Landbouwwet. Rijksuniv. Gent. 49:587-596.

9. Conover, R. A., and Gerhold, R. A. 1981. Mixtures of copper and maneb or mancozeb for control of bacterial spot of tomato and their compatibility for control of fungus diseases Phytophthora infestans, Stemphylium solani, Xanthomonas campestris pv. vesicatoria, Florida. Proc. Fla. State Hortic. Soc. 94:154-156.

10. Flaherty, J. E., Jones, J. B., Harbaugh, B. K., Somodi, G. C., and Jackson, L. E. 2000. Control of bacterial spot on tomato in the greenhouse and field with H-mutant bacteriophages. HortScience 35:882-884.

11. Florida Tomato Committee. Florida Tomato Facts and Sizing. 2002.

12. Hert, A. P. 2001. Relative importance of bacteriocin-like genes in antagonism of $\mathrm{T} 3$ to $\mathrm{T} 1$ strains of Xanthomonas campestris pv. vesicatoria. Master's thesis, University of Florida.

13. Horsfall, J. G., and Barratt, R. W. 1945. An improved system for measuring plant disease. (Abstr.) Phytopathology 35:655

14. Ji, P., Kloepper, J. W., Wilson, M., and Campbell, H. L. 1996. Rhizobacterial-induced systemic resistance in tomato against bacterial speck. (Abstr.) Phytopathology 86:S50.

15. Jindal, K. K., and Thind, B. S. 1993. Biological control of bacterial blight of cowpea (Vigna unguiculata L. Walp.). Phytopathol. Mediterr. 32:193-200.

16. Jindal, K. K., and Thind, B. S. 1994 Evaluation of green gram microflora for control of Xanthomonas campestris pv. vignaeradiatae, the incitant of bacterial leaf spot. Plant Dis. Res. 9:10-19.

17. Jones, J. B., Bouzar, H., Somodi, G. C., Stall, R. E., Pernezny, K., El-Morsy, G., and Scott, J. W. 1998. Evidence for the preemptive nature of tomato race 3 of Xanthomonas campestris pv. vesicatoria in Florida. Phytopathology 88:33-38.

18. Jones, J. B., and Jones, J. P. 1985. The effect of bactericides, tank mixing time and spray schedule on bacterial leaf spot of tomato. Proc.
Fla. State Hortic. Soc. 98:244-247.

19. Jones, J. B., Jones, J. P., Stall, R. E., and Zitter, T. A. 1991. Compendium of Tomato Diseases. American Phytopathological Society Press. St. Paul, MN.

20. Jones, J. B., Obradovic, A., Balogh, B., Momol, M. T., and Jackson, L. E. 2002. Control of bacterial leaf spot on tomato with bacteriophages. (Abstr.) Phytopathology 92:S108.

21. Jones, J. B., Pohronezny, K. L., Stall, R. E., and Jones, J. P. 1986. Survival of Xanthomonas campestris pv. vesicatoria in Florida on tomato crop residue, weeds, seeds, and volunteer tomato plants. Phytopathology 76:430434.

22. Jones, J. B., Stall, R. E., and Bouzar, H. 1998. Diversity among xanthomonads pathogenic on pepper and tomato. Annu. Rev. Phytopathol. 36:41-58

23. Jones, J. B., Stall, R. E., Scott, J. W., Somodi, G. C., Bouzar, H., and Hodge, N. C. 1995. A third tomato race of Xanthomonas campestris pv. vesicatoria. Plant Dis. 79:395-398.

24. Jones, J. B., Woltz, S. S., Jones, J. P., and K. L. Portier. 1991. Population dynamics of Xanthomonas campestris pv. vesicatoria on tomato leaflets treated with copper bactericides. Phytopathology 81:714-719.

25. Kousik, C. S., and Ritchie, D. F. 1996. Race shift in Xanthomonas campestris pv. vesicatoria within a season in field-grown pepper. Phytopathology 86:952-958.

26. Kucharek, T. 1994. Bacterial spot of tomato and pepper. Plant pathology fact sheet. PP-3. University of Florida, Gainesville.

27. Lindow, S. E., McGourty, G., and Elkins, R. 1996. Interactions of antibiotics with Pseudomonas fluorescens A506 in the control of fire blight and frost injury to pear. Phytopathology 86:841-848.

28. Louws, E. J., Wilson, M., Campbell, H. L., Cuppels, D. A., Jones, J. B., Shoemaker, P. B., Sahin, F., and Miller, S. A. 2001. Field control of bacterial spot and bacterial speck of tomato using a plant activator. Plant Dis. 85:481-488.

29. Marco, G. M., and Stall, R. E. 1983. Control of bacterial spot of pepper initiated by strains of Xanthomonas campestris pv. vesicatoria that differ in sensitivity to copper. Plant Dis. 67:779-781.

30. Maynard, D. N., Hochmuth, G. J., Olson, S. M., Vavrina, C. S., Stall, W. M., Kucharek, T. A., Webb, S. E., Taylor, T. G., and Smith, S. A. 2001. Tomato production in Florida. Pages 257-267 in: Vegetable Production Guide for Florida, 2001-2002. D. N. Maynard and S. M.
Olson, eds. University of Florida, Institute of Food and Agricultural Sciences Extension Service, Gainesville.

31. Minsavage, G. V., Balogh, B., Stall, R. E., and Jones, J. B. 2003. New tomato races of Xan thomonas campestris pv. vesicatoria associated with mutagenesis of tomato race 3 strains. (Abstr.) Phytopathology 93:S62.

32. Momol, M. T., Olson, S. M., Funderburk, J. E. and Marois, J. J. 2003. Integrated management of tomato spotted wilt on tomato. (Abstr.) Phytopathology 93:S115.

33. Obradovic, A., Jones, J. B., Momol, M. T., Olson, S. M., King, P. C., and Balogh, B 2002. Management of tomato bacterial spot in the field by foliar applications of bacteriophages and SAR inducers. Phytopathology (Abstr.) 92:S60.

34. Pohronezny, K., and Volin, R. B. 1983. The effect of bacterial spot on yield and quality of fresh market tomatoes. HortScience 18:69-70.

35. Qui, D., Wei, Z. M., Bauer, D. W., and Beer, S. V. 1997. Treatment of tomato seed with harpin enhances germination and growth and induces resistance to Ralstonia solanacearum. (Abstr.) Phytopathology 87:S80.

36. Ritchie, D. F., and Dittapongpitch, V. 1991 Copper- and streptomycin-resistant strains and host differentiated races of Xanthomonas campestris pv. vesicatoria in North Carolina. Plant Dis. 75:733-736.

37. Romero, A. M., Kousik, C. S., and Ritchie, D. F. 2001. Resistance to bacterial spot in bell pepper induced by acibenzolar- $S$-methyl. Plant Dis. 85:189-194.

38. Sherf, A. F., and Macnab, A. A. 1986. Vegetable Diseases and Their Control. John Wiley and Sons, New York.

39. Stall, R. E., and Thayer, P. L. 1962. Streptomycin resistance of the bacterial spot pathogen and control with streptomycin. Plant Dis. Rep. 46:389-392.

40. Tudor-Nelson, S. M, Minsavage, G. V., Stall, R. E., and Jones, J. B. 2003. Bacteriocin-like substances from tomato race 3 strains of Xanthomonas campestris pv. vesicatoria. Phytopathology 93:1415-1421.

41. Wilson, M., Campbell, H. L., Ji, P., Jones, J. B., and Cuppels, D. A. 2002. Biological control of bacterial speck of tomato under field conditions at several locations in North America. Phytopathology 92:1284-1292.

42. Wilson, M., Campbell, H. L., Jones, J. B., Suslow, T. V., and Cuppels, D. A. 1997. Biological control of bacterial speck of tomato. (Abstr.) Phytopathology 86:S49. 